\title{
Mature Archean continental crust in the Yangtze craton: Evidence from petrology, geochronology and geochemistry
}

\author{
WANG ZhengJiang ${ }^{1}$, WANG Jian ${ }^{1 *}$, DU QiuDing ${ }^{1}$, DENG Qi ${ }^{1,2}$, YANG Fei $^{1,3} \&$ WU Hao ${ }^{1,2}$ \\ ${ }^{1}$ Chengdu Institute of Geology and Mineral Resources, Ministry of Land and Resources of the People's Republic of China, \\ Chengdu 610082, China; \\ ${ }^{2}$ Graduate Faculty of Chinese Academy of Geological Sciences, Beijing 100037, China: \\ ${ }^{3}$ Graduate Faculty of Shandong University of Science and Technology, Qingdao 266510, China
}

Received November 5, 2012; accepted December 27, 2012; published online February 1, 2013

\begin{abstract}
Previous studies have shown that the Archean basement is widely distributed throughout the Yangtze craton. To date, however, Archean basement terrains have not been found, except for a few Kongling high-grade metamorphic terrains in the Huangling dome that have been confirmed to be of Archean age. To further understand the basement component and crustal evolution of the Yangtze craton, we carried out a petrological, geochronological and geochemical study of the Jinshan K-feldspar granite emplaced within the Yangpo Group, located in Huji Town, Zhongxiang City, Hubei Province. Results indicate that the zircon SHRIMP U-Pb age of the Jinshan granite is $2655 \pm 9 \mathrm{Ma}$, placing it within the middle Neoarchean. Chemically, this pluton yields abundant silica and alkalis and is depleted in $\mathrm{Ca}, \mathrm{Mg}$ and Ti. Furthermore, it is enriched in $\mathrm{Rb}, \mathrm{Th}, \mathrm{Ga}, \mathrm{Y}$ and $\mathrm{Zr}$, depleted in $\mathrm{Sr}$, $\mathrm{Ba}, \mathrm{Nb}$ and $\mathrm{Ta}$, and especially lacking in Eu. High ratios of $\mathrm{FeO} * \mathrm{MgO}(32.0$ to 58.7$)$ and $10^{4} \times \mathrm{Ga} / \mathrm{Al}$ (3.19 to 3.41) were also found. The pluton exhibits characteristics typical of A-type granites with crustal source magmas. Moreover, the meta-sedimentary rock association of the Yangpo Group, into which the pluton intruded, clearly shows relatively stable depositional environments of a shallow shelf sequence. Therefore, before the middle Neoarchean, the Yangtze craton contained mature continental crust. This breakthrough discovery opens a new window on the study of the formation and evolution of the Yangtze craton basement.
\end{abstract}

Yangtze craton, Neoarchean, mature continental crust, A-type granite, Yangpo Group

Citation: Wang Z J, Wang J, Du Q D, et al. Mature Archean continental crust in the Yangtze craton: Evidence from petrology, geochronology and geochemistry. Chin Sci Bull, 2013, 58: 2360-2369, doi: 10.1007/s11434-013-5668-7

Since 2000, studies on the basement evolution of the Kongling terrain in the Yangtze craton have advanced our knowledge considerably [1-9]. However, there are few very old rock outcrops exposed in the region. To overcome this difficulty, Zhang et al. [10] carried out U-Pb dating and Hf isotope research on Neoproterozoic clastic zircons, Bai et al. [11] evaluated whole-rock Nd isotopic tracers in Proterozoic and Paleozoic sedimentary rocks, and Zheng et al. [12] conducted $\mathrm{U}-\mathrm{Pb}$ dating of xenocrystic zircons brought to the surface in lamproite diatremes. These studies collectively demonstrated that the Yangtze craton contains widely distributed Archean crystalline basement. However, Archean outcrops are reported only rarely from other parts of the

*Corresponding author (email: w1962jian@163.com)
Yangtze craton, except for the Kongling terrain, in which highly metamorphosed Archean rocks have been confirmed $[2,7,8]$.

Previously the Hubei Institute of Geological Survey regarded a K-granite pluton in the Yangpo Group of the Huji region as Neoproterozoic in age, comparable to the Huashanguan K-granite in the Lingkuang region and the Quanqitang K-granite in the northern Huangling anticline [13]. Nonetheless, current research indicates that the age of the Quanqitang pluton is $1854 \mathrm{Ma}[3,8,14]$, and the age of the Huanshanguan pluton is $1851 \mathrm{Ma}$ [15]. Hence, both of these plutons are middle-late Paleoproterozic in age, and they share the same tectonic setting associated with rifting of the Columbia supercontinent during the Paleoproterozic.

Thus, it is still unresolved as to whether the Jianshan 
K-granite in the Huji region of Hubei Province has the same or similar age and tectonic setting to the Huashanguan and Quanqitang plutons. Herein, we report on the isotopic geochronology, petrology and geochemistry of the Jinshan $\mathrm{K}$-granite emplaced in the Yangpo Group of the Huji region. Results shed light on the formation and early evolution of the Yangtze craton.

\section{Geological setting and sampling}

The Yangpo Group outcrop area extends along a northweststriking narrow belt (Fangmashan-Yangjiapo), over an area of about $8 \mathrm{~km}^{2}$ in the Huji region of Zhongxiang City, along the west bank of the Hanshui River in the interior of the Yangtze Block. This depositional sequence is overlain by tillite of the Nantuo Formation of the Nanhua System to the west, and covered by Quaternary sediments to the east. The Yangpo Group has been intruded by K-granites in its northern and southern reaches. Therefore, the Yangpo sequence is considered to constitute the basement rocks of the Yangpo horst in the Zhongxiang fault-rift [16] (Figure 1(b)). However, the Yangpo Group is not exposed in its entirety, since its base was intruded and therefore obscured by the
K-granite pluton.

Yangpo rocks are mainly composed of mica schists, granulite, quartzite and quartzose wackestone, with a few amphibolite intercalations [16]. These observations suggest that the protolith was a shallow marine shelf sedimentary sequence deposited in a relatively stable tectonic setting. Geologic mapping indicates that the K-granites emplaced within the Yangpo Group are mainly stocks or apophyses, with the largest stock (about $3 \mathrm{~km}^{2}$ ) located in Jinshan to Wangji Village areas of Huji Town (Figure 1(b)). Macroscopically the oriented biotites impart a bedded appearance or zebra structure to the granites.

Samples for this study were collected from west of Jinshan Village (DHS16-1, -3, -5) and south of Wangji Village (DHS16-2, -4, -6, -7) in Huji Town. The GPS coordinates of the two localities are $31^{\circ} 27^{\prime} 21^{\prime \prime} \mathrm{N}, 112^{\circ} 15^{\prime} 56^{\prime \prime} \mathrm{E}$, and $31^{\circ} 28^{\prime} 26^{\prime \prime} \mathrm{N}, 112^{\circ} 14^{\prime} 46^{\prime \prime} \mathrm{E}$, respectively.

The samples are purplish red in color with coarse-grained porphyritic textures. Major minerals are K-feldspar (30\%$45 \%)$, plagioclase $(20 \%-35 \%)$, quartz $(20 \%-25 \%)$, and biotite $(<3 \%)$. Ilmenite, apatite and zircon are the main accessory minerals $(<1 \%)$. K-feldspars (ca. $5 \mathrm{~mm}$ in diameter) are mainly orthoclase with minor perthite and microcline. They are granular in shape, and irregularly intercalated with

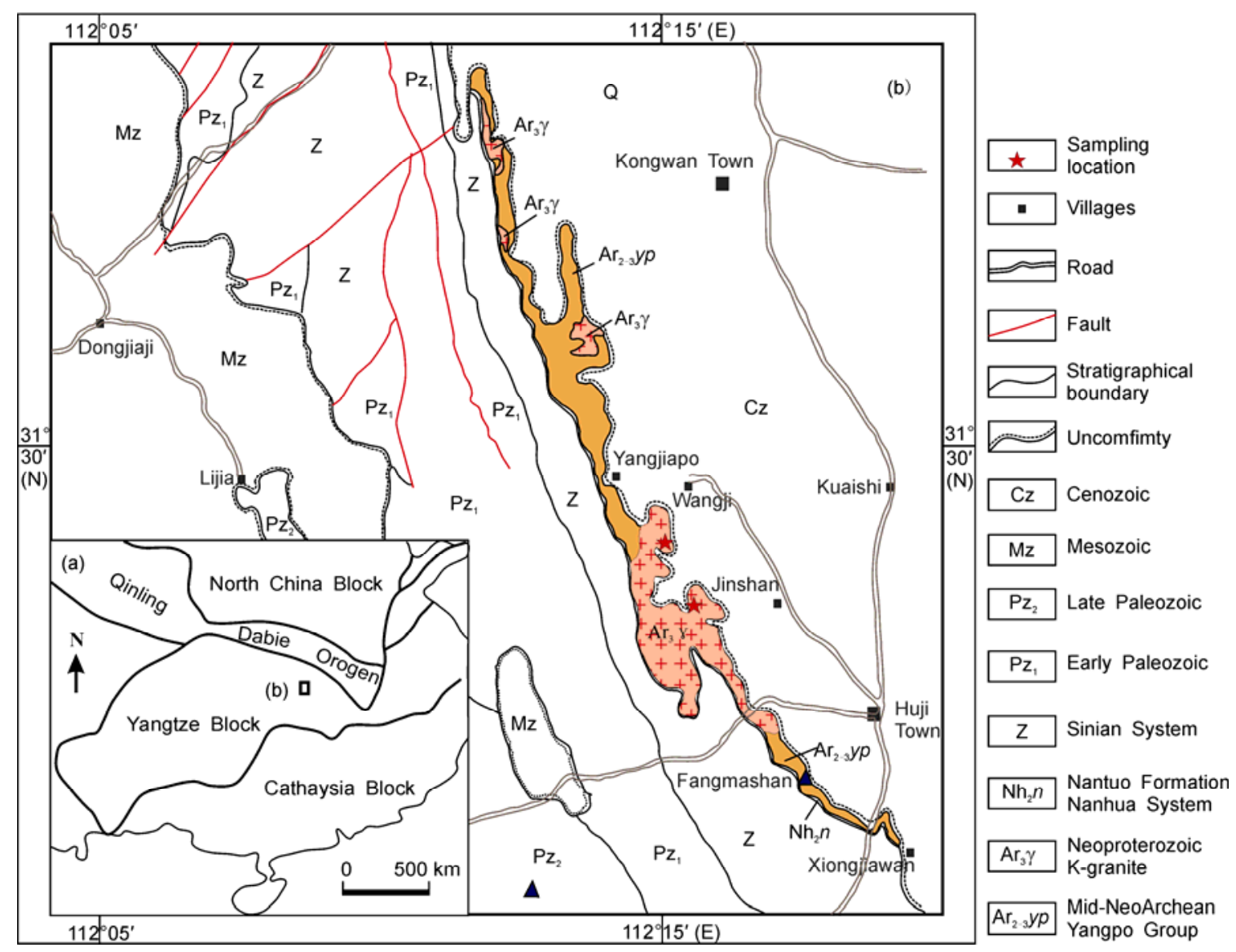

Figure 1 Geological sketch map for the Huji region of Zhongxiang City, Hubei Province. 
plagioclase. Some large grains generally contain quartz and plagioclase micro-crystals. Plagioclases are mainly oligoclase and albites typified by regular tabular crystals and development of multiple twinning, and some grains contain quartz micro-crystals. Quartz occurs as subhedral to anhedral crystals of $0.5-1 \mathrm{~mm}$ diameter that irregularly fill the gaps between feldspars. Some quartz crystals show wavy extinction.

\section{Analytical methods}

Whole-rock major elements were analyzed by X-ray fluorescence (XRF) using glass disks at the Southwest Monitoring Center of Geological and Mineral Resources, Ministry of Land and Resources, PRC. The $\mathrm{FeO}$ contents were determined using a wet chemical method. Analysis of international standards (BCR-2, GSR-1 and GSR-3) indicated that both analytical precision and accuracy were better than $5 \%$. Whole-rock trace elements were analyzed at the State Key Laboratory of Geological Processes and Mineral Resources, China University of Geosciences. About $50 \mathrm{mg}$ of powdered sample was digested by $\mathrm{HF}+\mathrm{HNO}_{3}$ in Teflon bombs and analyzed with an Agilent 7500a ICP-MS. The analytical precision was better than $5 \%$ for elements with concentrations greater than $10 \mathrm{ppm}$, and less than $10 \%$ for those with concentrations less than $10 \mathrm{ppm}$. A total of seven samples from the Jinshan granite were selected for wholerock major and trace element analysis. Results are listed in Table 1.

Zircon crystals from samples DHS16-1 were separated by standard techniques (i.e. heavy liquid and magnetic separation). Then, transparent zircon grains were selected using a binocular microscope. The representative grains, together with standard zircon TEMORA 1 (417 Ma), were mounted in an epoxy resin mount and polished until the crystal cores were exposed. The polished mounts were documented and photographed under transmitted and reflected light and cathodoluminescence (CL). Operating conditions for CL imaging were $15 \mathrm{kV}$ and $4 \mathrm{nA}$. Typical CL images were obtained to characterize each grain in terms of size, growth morphology and internal structure, and used to guide analytical spot selection for U-Pb dating. Then, the mounts were vacuum-coated with a layer of gold. The $\mathrm{U}, \mathrm{Th}$ and $\mathrm{Pb}$ isotope compositions were analyzed using SHRIMP II at Beijing Ion Microprobe Analysis Center, Chinese Academy of Geological Sciences, following the procedures described by [17].

$\mathrm{U}-\mathrm{Th}-\mathrm{Pb}$ ratios were determined relative to the TEMROA zircon standard, and the $\mathrm{U}$ and $\mathrm{Th}$ absolute abundances were analyzed relative to the SL13 zircon standard. Common lead for both standard and unknown samples were corrected by measured ${ }^{204} \mathrm{~Pb}$. Uncertainties on individual analyses in data tables are reported to $1 \sigma$ significance. Mean ages for pooled ${ }^{206} \mathrm{~Pb} /{ }^{238} \mathrm{U}$ and ${ }^{207} \mathrm{~Pb} /{ }^{206} \mathrm{~Pb}$ analyses are cited with $95 \%$ confidence, unless otherwise stated. The data were processed using the SQUID and ISOPLOT programs of Ludwig. Zircon U-Pb data are listed in Table 2.

\section{Results}

\subsection{Whole-rock major and trace elements}

In general, the samples had high $\mathrm{SiO}_{2}$ contents, ranging from $76.82 \%$ to $77.91 \%$, and high alkali contents, specifically with $\mathrm{K}_{2} \mathrm{O}$ of $5.22 \%-5.58 \%$ and $\mathrm{Na}_{2} \mathrm{O}$ of $2.26 \%$ $2.72 \%$. The samples were similar in composition to $\mathrm{A}_{2}$-type granites [18-20], with low $\mathrm{Fe}_{2} \mathrm{O}_{3}(2.08 \%-2.62 \%), \mathrm{CaO}$ $(0.10 \%-0.24 \%), \mathrm{MgO}(0.040 \%-0.077 \%), \mathrm{TiO}_{2}(0.25 \%-$ $0.30 \%$ ), and $\mathrm{P}_{2} \mathrm{O}_{5}(0.025 \%-0.046 \%)$ contents (Table 1$)$, and a high $\mathrm{FeO}^{\mathrm{T}} / \mathrm{MgO}$ ratio (32-58).

The studied samples were plotted in the field of alkaline rocks in the $\mathrm{AR}$ vs. $\mathrm{SiO}_{2}$ diagram (not shown). Their $\mathrm{Al}_{2} \mathrm{O}_{3}$ contents were between $10.43 \%$ and $11.18 \%$, exhibiting an aluminous feature $(\mathrm{A} / \mathrm{KNC}=1.05-1.08)$. Their differentiation index was high (DI of 94.7-96.0), and they exhibited low $\mathrm{Fe}, \mathrm{Mg}, \mathrm{Ti}$ and $\mathrm{P}$. These observations indicate that the magma underwent a high degree of differentiation.

In the primitive mantle-normalized [21] spider diagram (Figure 2(a)), all samples show characteristic negative anomalies of Ba, Nb, Ta, Sr, P, Eu and Ti. The negative Ba, $\mathrm{Sr}$ and $\mathrm{Eu}$ anomalies may be associated with residual plagioclase in the magma source, whereas the negative $\mathrm{P}$ and $\mathrm{Ti}$ anomalies are likely to be attributed to residual apatite. At the same time, all samples show positive anomalies of $\operatorname{HFSE}(\mathrm{Zr}, \mathrm{Hf}, \mathrm{Y})$ and LILE (Rb, U, Th, La), and the $10^{4} \times$ $\mathrm{Ga} / \mathrm{Al}$ ratio of all samples varied from 3.19 to $3.41(>2.6)$. These observations collectively indicate typical geochemical characteristics of A-type granites [22].

Compared with typical I-type granites, all the samples exhibited high REE contents, relatively high enrichment of the light rare earth elements (LREEs) $\left([\mathrm{La} / \mathrm{Yb}]_{\mathrm{N}}\right.$ ratios of 4.20 to 9.42]), flat HREE patterns and strongly negative Eu anomalies, and some samples showed weak positive or negative $\mathrm{Ce}$ anomalies (Figure 2(b)). Moreover, samples DHS16-2, -4, -6, -7 were distinctly rich in LREE. DHS16-7, in particular, was not only rich in LREE, but also in HREE. The $\sum$ REE was as high as $785.99 \mathrm{ppm}$. However, all samples had the same or similar curve shape in primitive mantle-normalized spider diagrams and chondrite-normalized REE patterns (Figure 2), which suggest that they had the same magma source.

\subsection{Zircon U-Pb SHRIMP age}

Zircon grains recovered from sample DHS16-1 were euhedral and prismatic $(80-200 \mu \mathrm{m})$, with aspect ratios of 1.5:1 to $3: 1$. Most of them were transparent and light rose in color. As shown in Figure 3, simple internal oscillatory zoning 


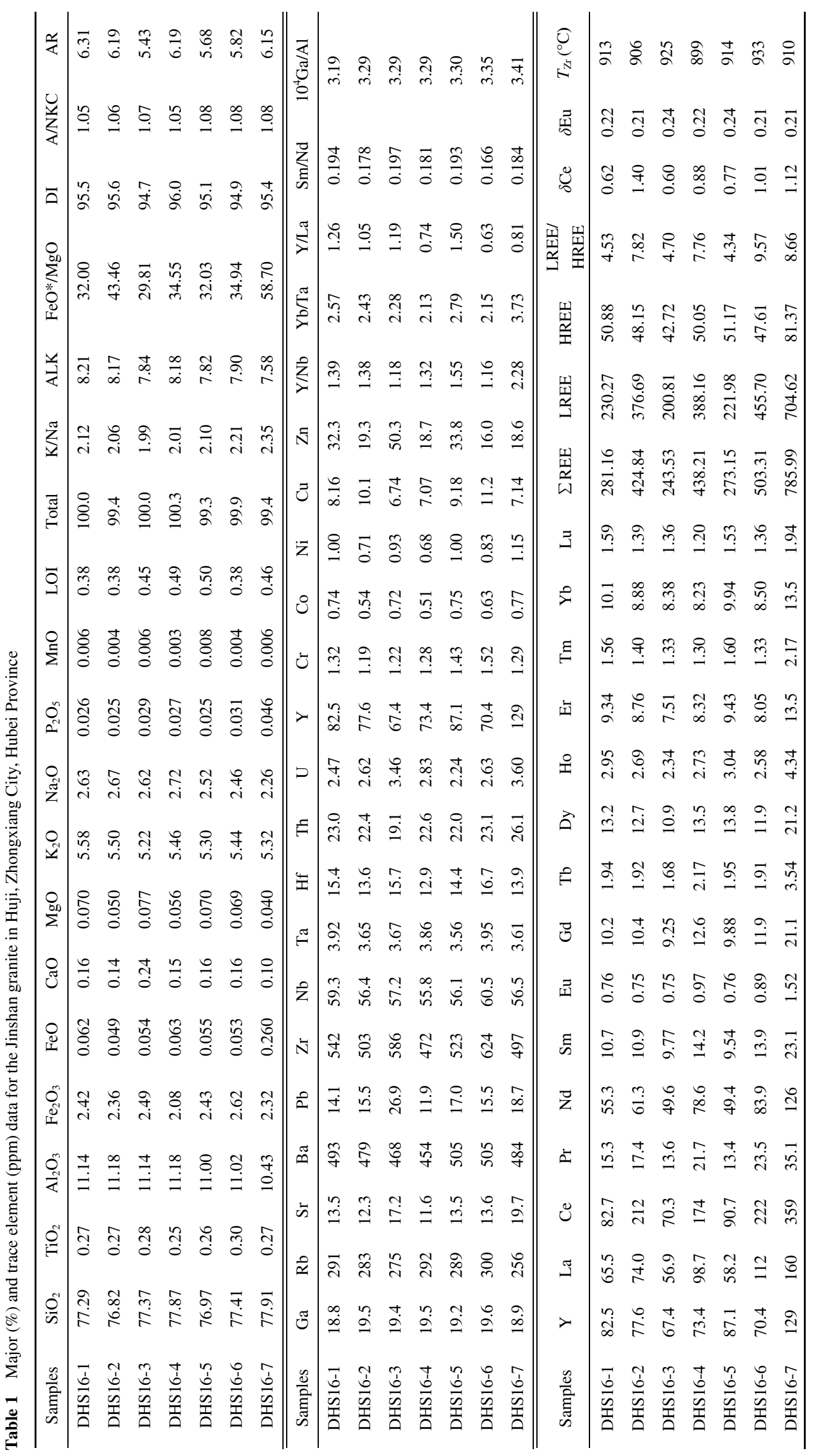


Table 2 SHRIMP zircon U-Pb isotope data for the Jinshan granite in Huji, Zhongxiang City, Hubei Province

\begin{tabular}{|c|c|c|c|c|c|c|c|c|c|c|c|}
\hline \multirow{2}{*}{$\begin{array}{c}\text { DHS16 } \\
\text { spot }\end{array}$} & \multirow{2}{*}{$\begin{array}{c}\left.{ }^{206} \mathrm{~Pb}_{\mathrm{c}}{ }^{\mathrm{a}}\right) \\
(\%)\end{array}$} & \multirow{2}{*}{$\begin{array}{c}\mathrm{U} \\
\left(10^{-6}\right)\end{array}$} & \multirow{2}{*}{$\begin{array}{c}\text { Th } \\
\left(10^{-6}\right)\end{array}$} & \multirow{2}{*}{$\begin{array}{c}{ }^{206} \mathrm{~Pb}^{* a)} \\
\left(10^{-6}\right)\end{array}$} & \multirow{2}{*}{${ }^{232} \mathrm{Th} /$} & ${ }^{206} \mathrm{~Pb} /{ }^{238} \mathrm{U}$ & ${ }^{207} \mathrm{~Pb} /{ }^{206} \mathrm{~Pb}$ & ${ }^{207} \mathrm{~Pb} /{ }^{235} \mathrm{U}$ & ${ }^{206} \mathrm{~Pb}^{*} /{ }^{238} \mathrm{U}$ & ${ }^{207} \mathrm{~Pb}^{*} /{ }^{206} \mathrm{~Pb}^{*}$ & \multirow{2}{*}{$\begin{array}{c}\text { Discordance }^{\mathrm{c})} \\
(\%)\end{array}$} \\
\hline & & & & & & \multicolumn{3}{|c|}{ Isotope ratio $( \pm \%)^{\mathrm{b})}$} & \multicolumn{2}{|c|}{$\operatorname{Age}(\mathrm{Ma})^{\mathrm{b})}$} & \\
\hline 1.1 & 0.16 & 134 & 70 & 50.1 & 0.54 & $0.4332 \pm 0.81$ & $0.1715 \pm 0.71$ & $10.24 \pm 1.1$ & $2320 \pm 16$ & $2572 \pm 12$ & 10 \\
\hline 2.1 & 0.07 & 148 & 84 & 63.4 & 0.59 & $0.4971 \pm 0.77$ & $0.1795 \pm 0.57$ & $12.30 \pm 0.9$ & $2601 \pm 16$ & $2648 \pm 9$ & 2 \\
\hline 3.1 & 0.08 & 124 & 59 & 55.3 & 0.49 & $0.5187 \pm 0.81$ & $0.1800 \pm 0.61$ & $12.87 \pm 1.0$ & $2694 \pm 18$ & $2653 \pm 10$ & -2 \\
\hline 4.1 & 0.16 & 122 & 62 & 53.4 & 0.53 & $0.5093 \pm 2.00$ & $0.1811 \pm 0.68$ & $12.72 \pm 2.1$ & $2653 \pm 42$ & $2663 \pm 11$ & 0 \\
\hline 5.1 & 0.45 & 82 & 31 & 35.0 & 0.39 & $0.4940 \pm 1.00$ & $0.1750 \pm 0.99$ & $11.92 \pm 1.4$ & $2588 \pm 22$ & $2606 \pm 16$ & 1 \\
\hline 6.1 & 0.29 & 112 & 45 & 49.8 & 0.41 & $0.5171 \pm 0.81$ & $0.1796 \pm 0.70$ & $12.81 \pm 1.1$ & $2687 \pm 18$ & $2649 \pm 12$ & -1 \\
\hline 7.1 & 0.10 & 96 & 62 & 43.3 & 0.66 & $0.5242 \pm 0.92$ & $0.1811 \pm 0.70$ & $13.09 \pm 1.2$ & $2717 \pm 20$ & $2663 \pm 12$ & -2 \\
\hline 8.1 & 0.14 & 110 & 59 & 49.9 & 0.55 & $0.5261 \pm 0.84$ & $0.1788 \pm 0.65$ & $12.97 \pm 1.1$ & $2725 \pm 19$ & $2641 \pm 11$ & -3 \\
\hline 9.1 & 0.49 & 371 & 31 & 70.1 & 0.09 & $0.2186 \pm 0.56$ & $0.1322 \pm 0.80$ & $3.98 \pm 1.0$ & $1275 \pm 7$ & $2127 \pm 14$ & 40 \\
\hline 10.1 & 0.12 & 116 & 45 & 50.8 & 0.40 & $0.5086 \pm 0.82$ & $0.1814 \pm 0.63$ & $12.72 \pm 1.0$ & $2651 \pm 18$ & $2666 \pm 10$ & 1 \\
\hline 11.1 & 0.07 & 131 & 55 & 58.1 & 0.43 & $0.5177 \pm 1.20$ & $0.1823 \pm 0.57$ & $13.02 \pm 1.4$ & $2690 \pm 27$ & $2674 \pm 9$ & -1 \\
\hline 12.1 & 0.08 & 130 & 57 & 55.3 & 0.45 & $0.4951 \pm 1.40$ & $0.1814 \pm 0.57$ & $12.38 \pm 1.5$ & $2593 \pm 30$ & $2666 \pm 9$ & 3 \\
\hline 13.1 & 0.09 & 126 & 57 & 50.7 & 0.47 & $0.4679 \pm 0.88$ & $0.1800 \pm 0.89$ & $11.61 \pm 1.3$ & $2474 \pm 18$ & $2653 \pm 15$ & 7 \\
\hline 14.1 & 0.07 & 150 & 82 & 65.1 & 0.56 & $0.5049 \pm 1.00$ & $0.1794 \pm 0.54$ & $12.49 \pm 1.2$ & $2635 \pm 22$ & $2647 \pm 9$ & 0 \\
\hline
\end{tabular}

a) $\mathrm{Pb}_{\mathrm{c}}$ and $\mathrm{Pb} *$ indicate the common and radiogenic portions, respectively; b) Common $\mathrm{Pb}$ corrected using measured ${ }^{204} \mathrm{~Pb}$, errors are $\left.1 \sigma ; \mathrm{c}\right)$ discordance $=100 \times\left(\right.$ Age $\left({ }^{207} \mathrm{~Pb} /{ }^{206} \mathrm{~Pb}\right)-$ Age $\left.\left({ }^{206} \mathrm{~Pb} /{ }^{238} \mathrm{U}\right)\right) /$ Age $\left({ }^{207} \mathrm{~Pb} /{ }^{206} \mathrm{~Pb}\right)$.
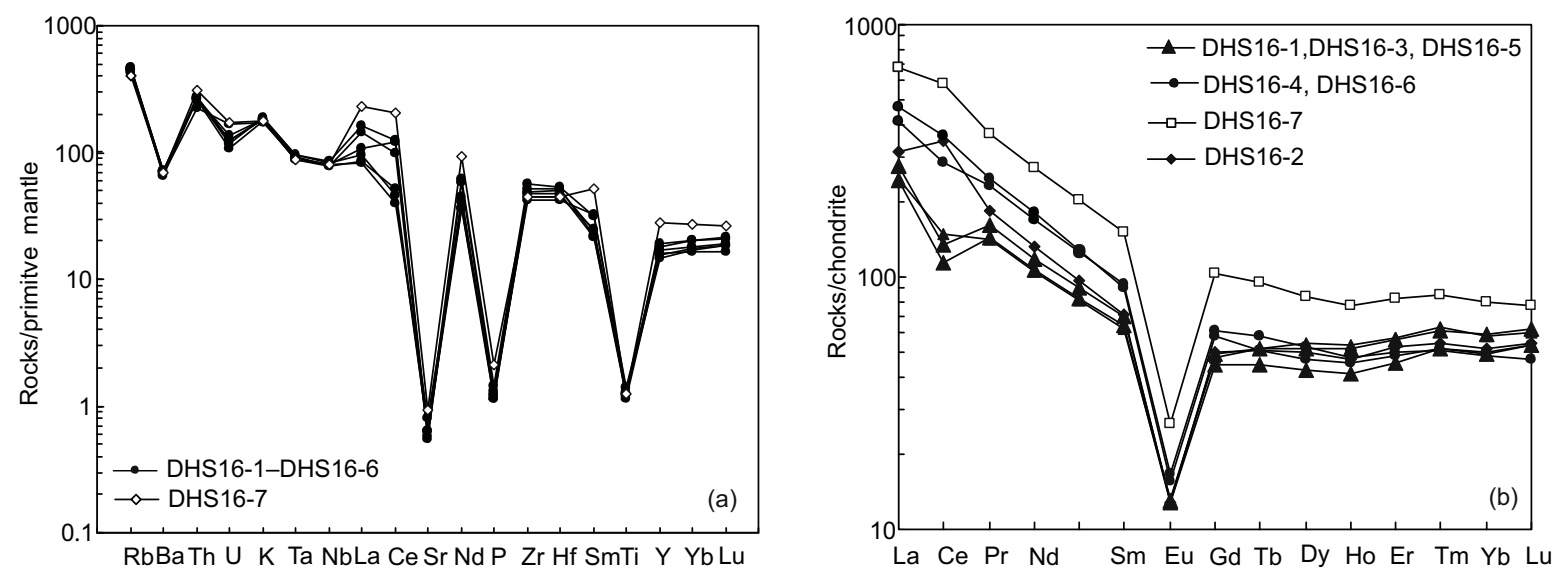

Figure 2 (a) Primitive mantle-normalized spider diagram of the Jinshan granite; (b) chondrite-normalized REE patterns of the Jinshan granite; primitive mantle and chondrite- normalized values are from [21].

was common and no inherited cores were observed. Nonetheless, some grains displayed corrosion pores (i.e. 6.1, 7.1, $12.1,13.1)$, which suggest that the pluton experienced hot events. The fact that the $\mathrm{Th} / \mathrm{U}$ ratio of zircon 9.1 was as low as 0.09 provides further evidence for these hot events.

A total of $14 \mathrm{U}-\mathrm{Pb}$ spots were analyzed on 14 zircon grains (Table 2). All the spots had moderate concentrations of $\mathrm{U}(82-150 \mathrm{ppm})$ and Th (31-84 ppm) with high $\mathrm{Th} / \mathrm{U}$ ratios of $0.39-0.66$ (Table 2), except for 9.1, which was consistent with a magmatic origin. They were concordant or slightly discordant, yielding a discordia plot with an upper intercept age of $2650 \pm 10 \mathrm{Ma}$ (MSWD=1.3, $n=14$ ) (Figure 4(a)). Except for spots 1.1 and 9.1, which showed lead loss, the remaining spots of the sample had coherent ${ }^{207} \mathrm{~Pb} /{ }^{206} \mathrm{~Pb}$ ages of $2606 \pm 16$ to $2674 \pm 9$ Ma. These coherent ages yielded a weighted average of $2655 \pm 9 \mathrm{Ma}(\mathrm{MSWD}=1.8, n=12)$ (Figure 4(b)), consistent with an upper intercept age within analytical uncertainties. These results verify that the Kgranite plutons emplaced within the Yangpo Group are Neoarchean in age, not Paleoproterozoic as originally inferred from previous research.

\section{Discussion}

\subsection{A-type affinity of the Jinshan granite}

Our preliminary study confirms that the Jinshan granite is an A-type granite. In fact, the term "A-type" granite describes a geochemical division of granites that are somewhat "alkaline", "anhydrous" and "anorogenic". Some A-type granites have index minerals, such as anhedral alkaline dark-colored minerals, fluorite, or thorium-rich zircon, but some metaluminous, even peraluminous granites without alkaline dark-colored minerals also could be A-type 


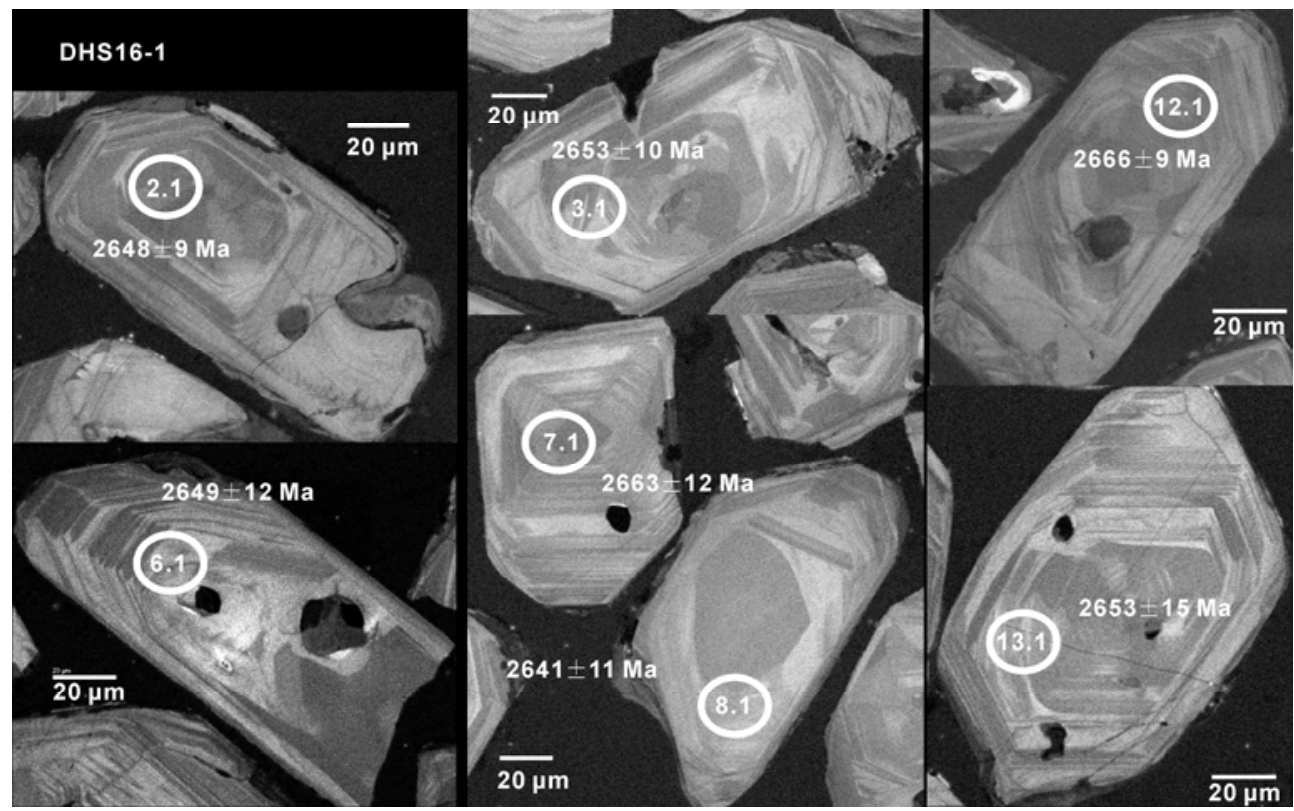

Figure 3 Typical CL images of the Jinshan granite at Huji. The circles and numbers show SHRIMP dating spots and corresponding ${ }^{207} \mathrm{~Pb} /{ }^{206} \mathrm{~Pb}$ ages.
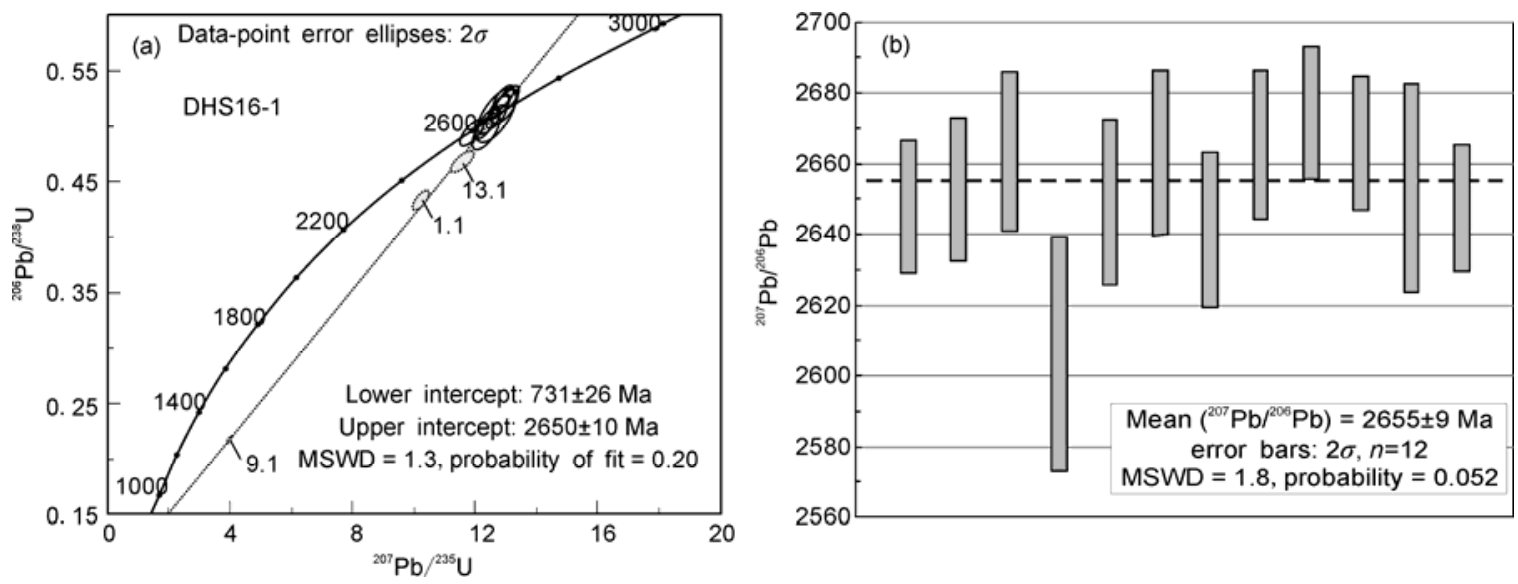

Figure 4 Concordia diagrams of SHRIMP zircon U-Pb dating for the Jinshan granite in the Huji region.

granites. Further studies have demonstrated that the A-type granites are compositionally diverse [19,23,24]. Therefore at present, discrimination of an A-type granite mainly relies on rock geochemistry diagrams.

The samples from the Jinshan granite all share geochemical features common to A-type granites. They show high $\mathrm{K}_{2} \mathrm{O}+\mathrm{Na}_{2} \mathrm{O}, \mathrm{Zr}, \mathrm{Nb}$ and $\mathrm{Ce}$ contents, and high $\mathrm{FeOt} /(\mathrm{FeOt}+$ $\mathrm{MgO})$ and $10^{4} \times \mathrm{Ga} / \mathrm{Al}$ ratios, which are typical for $\mathrm{A}_{2}$-type granites. In the discrimination diagrams of $\mathrm{SiO}_{2} \mathrm{vs}$. $\mathrm{Nb}$ [25], $\left(\mathrm{K}_{2} \mathrm{O}+\mathrm{Na}_{2} \mathrm{O}\right) / \mathrm{CaO}$ vs. $(\mathrm{Zr}+\mathrm{Nb}+\mathrm{Ce}+\mathrm{Y}), 10^{4} \times \mathrm{Ga} / \mathrm{Al}$ vs. $\mathrm{Zr}$ and $\mathrm{K}_{2} \mathrm{O}+\mathrm{Na}_{2} \mathrm{O}$ [22] (Figure 5), they all plot into the field of A-type granites. The Jinshan granite can easily be discriminated from S-type granites because the latter have much higher $\mathrm{P}_{2} \mathrm{O}_{5}$ contents, and are always peraluminous [24]. Compared with highly evolved I-type granites at the same $\mathrm{SiO}_{2}$ level, the Jinshan granite is comparatively enriched in $\mathrm{Zr}, \mathrm{Nb}, \mathrm{Y}, \mathrm{Ce}$ and $\mathrm{Ga}$. In $\mathrm{Rb} / \mathrm{Nb}$ vs. $\mathrm{Y} / \mathrm{Nb}$ and $\mathrm{Y}-$
Nd-Ce geochemical discriminating diagrams [18], the samples from the Jinshan granite are all plotted in the $\mathrm{A}_{2}$ group (not shown).

It is generally accepted that A-type granites are derived from relatively high temperature magmas. The calculated zircon saturation temperatures [26] for sample DHS16-1 range from 899 to $933^{\circ} \mathrm{C}$, with an average of $912^{\circ} \mathrm{C}$ (Table 1). This temperature is higher than typical I-type granites, but is similar to those of typical A-type granites worldwide [24]. Thus, it is clear that the Jinshan granite is most similar to aluminous A-type granites.

\subsection{Petrogenesis of the Jinshan K-granite}

Although controversy still exists in relation to the petrogenesis of A-type granites, it is generally accepted that the occurrence of A-type granite is commonly associated with an 

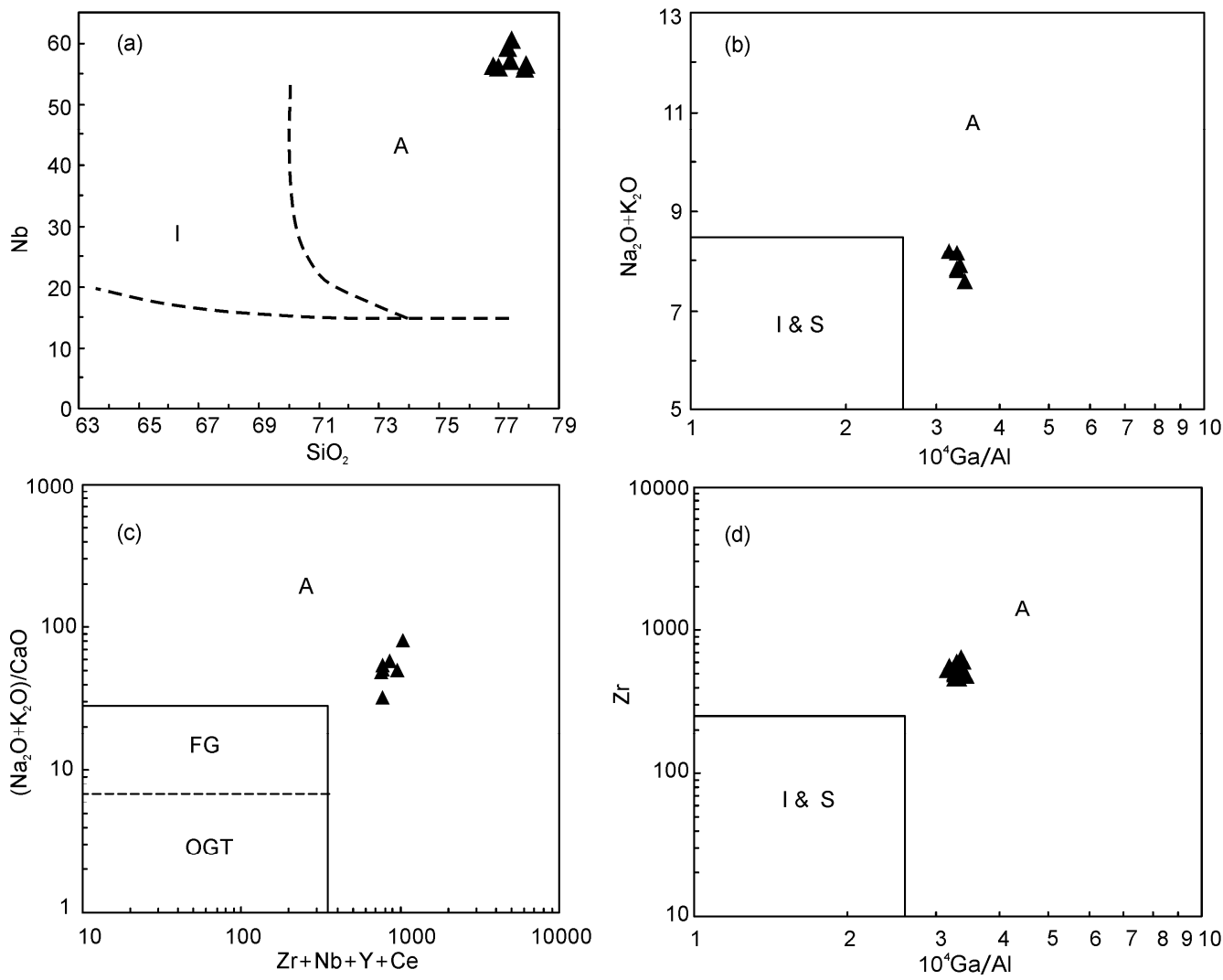

Figure 5 Discrimination diagrams $[22,25]$ for the Jinshan A-type granite in the Huji region. A, A-type granite; I, I-type granite; I \& S, I-type and S-type granite; FG, highly fractionated granite; OGT, unfractionated I-, S- and M-type granites.

extensional environment, either in post-orogenic or anorogenic settings [18-20,22-24,27-30].

It is well known that extensional settings are usually related to elevated heat in the shallow crust, such as mantle upwelling or basal magma diapirism. Wu et al. further noted that the material contribution to granite may be relatively little, although the heat brought up by the rising mantle material likely would be one of the main factors contributing to granite formation [29].

In fact, one of the characteristics of the Jinshan granite is that it is strongly depleted in Eu and $\mathrm{Sr}$, and rich in $\mathrm{Nb}$ and $\mathrm{Zr}$, which indicates that its magma source contained residual plagioclase and hence formed in a low pressure setting. Similarly, if high zircon saturation temperatures are taken into account, a developing tectonic setting characterized by low pressure and high temperature should be bound up with crustal extension resulting from mantle upwelling. Thus, the A-type granite magma not only would have brought a great amount of heat and deeper mantle material into the crust, it also would have led to remelting and reworking of crustal material on a large scale. In addition, it may have been the main style of crustal generation in the Archean before the plate tectonics mechanism came into action [31].

Eby [18] further subdivided A-type granites into $A_{1}$ and $A_{2}$ groups. The $A_{1}$ group represents differentiation of magmas derived from OIB-like sources and emplaced in an anorogenic setting, such as continental rift or intraplate environments. Conversely, the $\mathrm{A}_{2}$ group is derived from melting of continental crust or underplated mafic crust and emplaced in post-collisional or post-orogenic environments. Thus, Xue et al. [27] suggested that the A-type granites within plates or continents could indicate the timing and process of lithosphere reduction and asthenosphere upwelling. Yang et al. [32] further suggested that K-granites with low $\mathrm{Sr}$ and $\mathrm{Ba}$, and high HREE and $\mathrm{Y}$ contents should be derived from partial melting of the shallow juvenile crust.

Furthermore, in this study all samples of the Jinshan granite fall into the within plate fields (Figure 6) of the tectonic discrimination diagrams [33]. Therefore, it is inferred that the Jinshan aluminous A-type granite should be the product of within plate extension and crustal remelting due to reduced pressure resulting from the upwelling mantle.

Moreover, it is evident that the REE pattern of the Jinshan granite (Figure 2(b)) has weak but clearly positive or negative Ce anomalies. According to Schreiber et al. [34], Ce positive or negative anomalies are only found when crustal material has experienced strong weathering in an oxidizing environment, and such Ce anomalies should remain stable during metamorphism, even through to eclogite facies [35]. Thus, the measured $\mathrm{Ce}$ positive or negative anomalies provide another line of evidence to support the hypothesis that sediment originally formed under oxidizing 

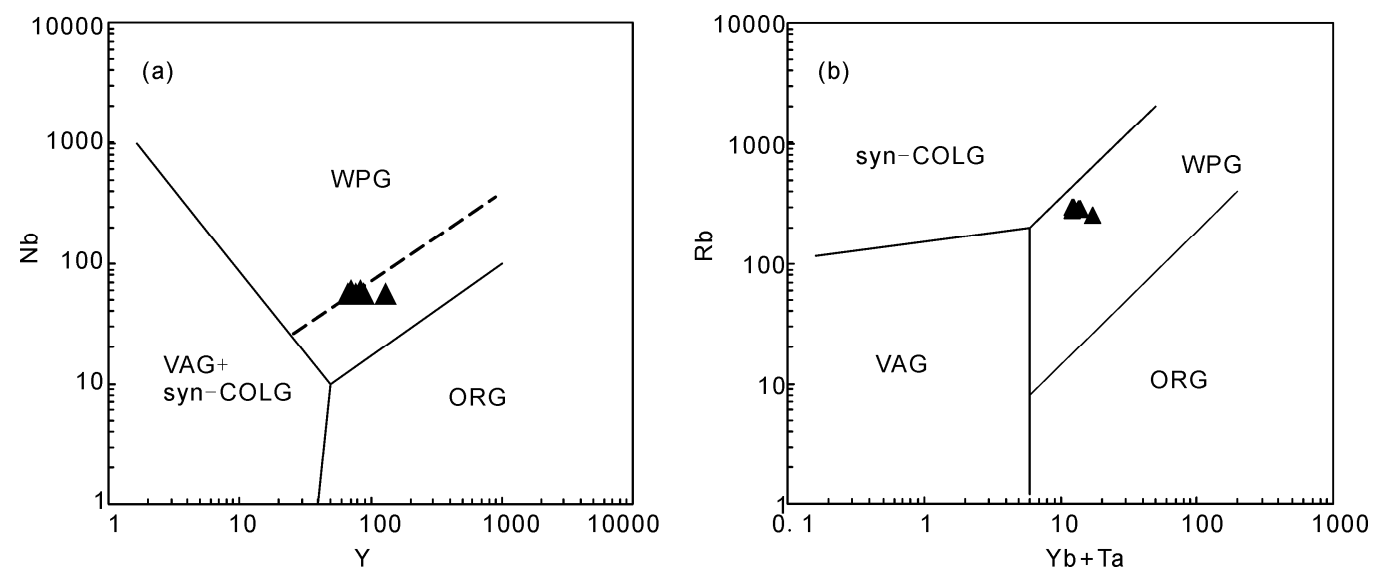

Figure $6 \mathrm{Nb}$ vs. Y and Rb vs. Yb+Ta diagrams [33]. WPG, Within-plate granites; ORG, ocean ridge granites; VAG, volcanic arc granites; syn-COL, synand post-collision granites.

conditions participated in the remelting process during emplacement of the Jinshan granite magma, confirming that it was derived from within plate extension and crustal remelting under reduced pressure.

\subsection{Archean continental basement beneath the Yangtze craton}

Previous studies have confirmed that the Yangtze craton contains widespread Archean basement [2,3,6,7,12]. However, still unclear are the locations and characteristics of the mature Archean crustal basement of the Yangtze craton. Based on data from Gao et al. [2] and Zhang et al. [7], we can verify that there is Archean crustal material in the Yangtze craton, but we cannot confirm the existence of a large-scale Archean geological body. To date, it has not been possible to identify the TTG gneiss in the Kongling region, which fingerprints the formation of primary crust in the Yangtze craton during the Archean [36]. As for the strata of the Kongling region, they may only be identified as middle Paleoproterozoic, constrained by the youngest zircon U-Pb concordance age [2] and the age of the Quanqitang granite $[4,8]$ emplacement, and these ages are similar to that of the Houhe complex [37] of Micang Mountain on the northern margin of the Yangtze Block. Furthermore, these strata and the Quanqitang granite are not associated with Archean geological bodies.

Because granites are the main constituents of the continental crust, and also are the key indices of maturity of crustal evolution [29], studies on continental evolution are based largely on investigations of granitic rocks. Granitic rocks related to the known stages of crustal evolution are tonalite $\left(\mathrm{T}_{1}\right)$, trondhjemite $\left(\mathrm{T}_{2}\right)$, granodiorite $\left(\mathrm{G}_{1}\right)$ and granite $\left(\mathrm{G}_{2}\right)$. Generally, it has been considered that Archean granitic rocks are mainly composed of tonalite, trondhjemite, and granodiorite (TTG), which represent the composition of primary continental crust, while the K-granites (mainly $\mathrm{G}_{2}$ with minor $\mathrm{G}_{1}$ ), indicating the nature continental crust, had not occurred until the early Paleoproterozoic [36].

Archean high pressure metamorphic rocks, granulite and gneiss, have been recovered from the Dabie Orogen [38]. To date within the Yangtze craton, the Quanqitang granite and Huashanguan pluton have been recorded as the oldest K-granites $[4,8,15]$, the age of which are middle Paleoproterozoic (ca. $1850 \mathrm{Ma}$ ). It is unclear whether the formation of mature continental crust of the Yangtze Block formed later than the North China Block [39].

Without doubt, the discovery of aluminous A-type granite emplaced in the Yangpo Group is an important breakthrough, because the age of the Jinshan granite (ca. 2655 $\mathrm{Ma}$ ) is clearly older than the K-granites known from the North China craton at present [39]. Hence, the Yangtze craton may have developed a Neoarchean basement or a mature continental block.

In fact, a stable platform was needed for the inferred tectonic activities to have occurred, including the emplacement of A-type granite, mantle upwelling, within plate extension, and reduced-pressure melting of crustal material. This scenario is consistent with stable sedimentary conditions reflected in the Yangpo Group depositional sequence, and experimental petrology has also confirmed that the parent magma of aluminous A-type granite was most likely derived from dehydro-melting of a felsic crust [40,41].

Furthermore, trace element $\mathrm{Sm} / \mathrm{Nd}, \mathrm{Y} / \mathrm{La}$ and $\mathrm{Y} / \mathrm{Nb}$ ratio averages of the Jinshan granite are $0.18,1.02$ and 1.46 , respectively (Table 1), quite different from the ratio averages $(0.32,6.42$ and 6.38$)$ of primitive mantle [42], and very close to the averages $(0.17,0.73$ and 0.88$)$ of upper crustal material [43]. In the spider diagram, the Jinshan granite is rich in LILE, and depleted in $\mathrm{Nb}$ and Ta (Figure 2(a)), which indicates that the magma source of the Jinshan granite should certainly have characteristics of the continental crust [44]. Thus, formation of the Jinshan K-granite suggests that a mature continental basement was well developed inside the Yangtze craton in the Neoarchean. This conclusion further verifies the hypothesis of Zhang and 
Zheng [45] that the crust and lithospheric mantle of the Yangtze Block mainly formed in the Archean.

\section{Conclusions}

An integrated study of zircon U-Pb ages and major and trace element analysis of the Jinshan granite in the Huji region reveals that the Yangtze Block has Archean basement, and mature continental crust had developed before the middle Neoarchean, as shown by:

(1) The Jinshan pluton in the Huji region constitutes a highly differentiated, alkaline, weak peraluminous A-type granite, with low $\mathrm{Sr}$ and $\mathrm{Ba}$, high HREE and $\mathrm{Y}$; it is rich in LILE, relatively depleted in $\mathrm{Nb}$ and $\mathrm{Ta}$, and contains clear Ce positive or negative anomalies, which suggest that the parent magma was derived from the within plate extension and crustal melting from reduced pressure resulting from mantle upwelling.

(2) The SHRIMP zircon U-Pb age of the K-granite pluton emplaced within the Yangpo Group is 2655 9 Ma, which is middle Neoarchean in age, not Paleoproterozoic, as previous studies had inferred.

(3) The characteristic trace elements of the Jinshan granite indicate that its magma source has the clear signature of continental crust.

Although the Yangpo Group and K-granite pluton emplaced within it are only a small fragment of the Archean crystallized basement in the Huji region, they open a new window on the study of the formation and evolution of the Yangtze craton.

We are grateful to Qing Zhu for assistance in sample analysis, Min Qikunfor rock-mineral identification, Liu Jianhui for SHRIMP zircon U-Pb dating, and Dr. Liang Chuntao for editing the manuscript. In addition, we thank Professor Lu Yuanfa for his Geokit software with which our chemical data were analyzed, and two anonymous reviewers for their comments, which helped to improve the manuscript. This work was supported by the National Natural Science Foundation of China (41030315 and 41072088) and the Chinese Geological Survey (1212011121111 and 1212011220750).

1 Qiu Y M, Gao S, McNaughton N J, et al. First evidence of $>3.2 \mathrm{Ga}$ continental crust in the Yangtze craton of South China and its implications for Archean crustal evolution and Phanerozoic tectonics. Geology, 2000, 28: 11-14

2 Gao S, Qiu Y M, Ling W L, et al. SHRIMP single zircon U-Pb dating of the Kongling high-grade metamorphic terrain: Evidence for $>3.2$ Ga old continental crust in the Yangtze craton. Sci China Ser D-Earth Sci, 2001, 44: 326-335

3 Ling W L, Gao S, Zhang B R, et al. The recognizing of ca. $1.95 \mathrm{Ga}$ tectono-thermal event in Kongling nucleus and its significance for the evolution of Yangtze Block, South China. Chin Sci Bull, 2001, 46: 326-329

4 Xiong Q, Zheng J P, Yu C M, et al. Zircon U-Pb age and Hf isotope of Quanyishang A-type granite in Yichang: Signification for the Yangtze continental cratonization in Paleoproterozoic. Chin Sci Bull, 2009, 54: 436-446

5 Jiao W F, Wu Y B, Peng M, et al. The oldest basement rock in the Yangtze Craton revealed by zircon $\mathrm{U}-\mathrm{Pb}$ age and $\mathrm{Hf}$ isotope composition. Sci China Ser D-Earth Sci, 2009, 52: 1393-1399
6 Peng M, Wu Y B, Wang J, et al. Paleoproterozoic mafic dyke from Kongling terrain in the Yangtze Craton and its implication. Chin Sci Bull, 2009, 54: 1098-1104

7 Zhang S B, Zheng Y F, Wu Y B, et al. Zircon isotope evidence for $\geqslant 3.5 \mathrm{Ga}$ continental crust in the Yangtze craton of China. Precambrian Res, 2006, 146: 16-34

8 Peng M, Wu Y B, Gao S, et al. Geochemistry, zircon U-Pb age and $\mathrm{Hf}$ isotope compositions of Paleoproterozoic aluminous A-type granites from the Kongling terrain, Yangtze Block: Constraints on petrogenesis and geologic implications. Gondwana Res, 2012, 22: 140151

9 Zhang S B, Zheng Y F. Growth and reworking of the Yangtze continental nucleus: Evidences from zircon $\mathrm{U}-\mathrm{Pb}$ ages and $\mathrm{Hf}$ isotopes (in Chinese). Acta Petrol Sin, 2007, 23: 393-402

10 Zhang S B, Zheng Y F, Wu Y B, et al. Zircon U-Pb age and Hf isotope evidence for $3.8 \mathrm{Ga}$ crustal remnant and episodic reworking of Archean crust in South China. Earth Planet Sci Lett, 2006, 252: 5671

11 Bai X, Ling W L, Duan R C, et al. Mesoproterozoic to Paleozoic Nd isotope stratigraphy of the South China continental nucleus and its geological significance. Sci China Ser D-Earth Sci, 2011, 54: 16651674

12 Zheng J P, Griffin W L, Suzanne Y O'Reilly, et al. Widespread Archean basement beneath the Yangtze craton. Geology, 2011, 34: 417420

13 Hubei Institute of Geological Survey. 1:250000 Regional Geological Survey Report of Jingmen City (in Chineses). 2005, 23-38

14 Yuan H H, Zhang Z L, Liu W, et al. Direct dating method of Zircon grains by ${ }^{207} \mathrm{~Pb} /{ }^{206} \mathrm{~Pb}$ (in Chinese). J Miner Petrol, 1991, 11: 72-79

15 Zhang L J, Ma C Q, Wang L X, et al. Discovery of Paleoproterozoic rapakivi granite on the northern margin of the Yangtze Block and its geological significance. Chin Sci Bull, 2011, 56: 306-318

16 Bureau of Geology and Mineral Resources of Hubei Province. Regional Geology of Hubei Province (in Chinese). Beijing: Geological Publishing House, 1990. 11-13

17 Liu D Y, Jian P, Kröner A, et al. Dating of prograde metamorphic events deciphered from episodic zircon growth in rocks of the DabieSulu UHP complex, China. Earth Planet Sci Lett, 2006, 250: 650-666

18 Eby G N. Chemical subdivision of the A-type granitoids: Petrogenesis and implications. Geology, 1992, 20: 641-644

19 Xue H M, Dong S W, Liou X C. Geochemical characteristics and their genesis of the granitic gneisses from southeastern Dabie Mountain. Acta Geol Sin, 2001, 14: 175-183

20 Liu C S, Chen X M, Chen P R, et al. Subdivision, discrimination criteria and genesis for A type rock suites (in Chinese). Geol J Chin Univ, 2003, 9: 573-591

21 Sun S S, McDonough W F. Chemical and isotopic systematics of oceanic basalts: Implications for mantle composition and processes. In: Saunders A D, Norry M J, eds. Magmatism in the Ocean Basins. London: Special Publications Geological Society, 1989, 42: 313-345

22 Whalen J B, Currie K L, Chappell B W. A-type granites: Geochemical characteristics,discriminatuon and petrogenesis. Contrib Miner Petrol, 1987, 95: 407-419

23 Richard P T, John N A, Mervin J. Neoproterozoic A-type granitoids of the central and southern Appalachians: Intraplate magmatism associated with episodic rifting of the Rodinian supercontinent. Precambrian Res, 2004, 128: 3-38

24 Bonin B. A-type granites and related rocks: Evolution of a concept, problems and prospects. Lithos, 2007, 97: 1-29

25 Collins W J, Bearns S D, White A J, et al. Nature and origin of A-type granites with particular reference to south-eastern Australia. Contr Mineral Petrol, 1982, 80: 189-200

26 Watson E B, Harrison T M. Zircon saturation revisited: Temperature and composition effect in a variety of crustal magmas types. Earth Planet Sci Lett, 1983, 64: 295-3041

27 Xue H M, Wang Y G, Ma F, et al. The Huanshan A-type granites with tetrad REE: Constraints on Mesozoic lithopheric thinning of the southeastern Yangtze craton (in Chinese). Acta Geol Sin, 2009, 83: 247-259 
28 Eby G N. The A-type granitoids: A review of their occurrence and chemical characteristics and speculation on their petrogenesis. Lithos, 1990, 26: 115-134

29 Wu F Y, Li X H, Yang J H, et al. Discussions on the petrogenesis of granites (in Chinese). Acta Petrol Sin, 2007, 23: 1217-1238

30 Zang Q, Pan G Q, Li C D, et al. Are discrimination diagrams always indicative of correct tectonic settings of granites? Some crucial questions on Granite study (3) (in Chinese). Acta Petrol Sin, 2007, 23: 2683-2698

31 Warren B. Hamilton. Archean magmatism and deformation were not products of plate tectonics. Precambrian Res, 1998, 91: 143-179

32 Yang J H, Wu F Y, Wilde Simon A, et al. Petrogenesis and geodynamics of Late Archean magmatism in eastern Hebei, eastern North China Craton: Geochronological, geochemical and Nd-Hf isotopic evidence. Precambrian Res, 2008, 167: 125-149

33 Pearce J A, Harris N B W, Tindle A G. Trace element discrimination diagrams for the tectonic interpretation of granitic rocks. J Petrol, 1984, 25: 956-983

34 Schreiber H D, Lauer H V, Thanyasir T. The redox state of cerium in basaltic magmas: An experimental study of iron-cerium interaction in silicate melts. Geochim Cosmochim Acta, 1980, 44: 1599-1612

35 Luo Y, Gao S, Yuan H L, et al. Ce anomaly in minerals of eclogite and garnet pyroxenite from Dabie-Sulu ultrahigh pressure metamorphic belt: Tacking subducted sediment formed under oxidizing conditions. Sci China Ser D-Earth Sci, 2004, 47: 920-930

36 Deng J F, Wu Z X, Zhao G C, et al. Precambrian granitic rocks, continental crustal evolution and craton formation of the North China Platform (in Chinese). Acta Petrol Sin, 1999, 15: 190-198

$37 \mathrm{Wu} \mathrm{Y} \mathrm{B,} \mathrm{Gao} \mathrm{S,} \mathrm{Zhang} \mathrm{H} \mathrm{F,} \mathrm{et} \mathrm{al.} \mathrm{Geochemistry} \mathrm{and} \mathrm{zircon} \mathrm{U-Pb}$ geochronology of Paleoproterozoic arc related granitoid in the Northwestern Yangtze Block and its geological implications. Precambrian Res, 2012, 200-203: 26-37

38 Wu Y B, Zheng Y F, Gao S, et al. Zircon U-Pb age and trace element evidence for Paleoproterozoic granulite-facies metamorphism and Archean crustal rocks in the Dabie Orogen. Lithos, 2008, 101: 308322

39 Geng Y S, Shen Q H, Ren L D. Late Neoarchean to Early Paleoproterozoic magmatic events and tectonic thermal systems in the North China Craton (in Chinese). Acta Petrol Sin, 2010, 26: 1945-1966

40 Crease R A, Price R C, Wormald R J. A-type granites revisited: Assessment of a residual-source model. Geology, 1991, 19: 163-166

41 Skjerlie K P and Johnston A D. Vapor-absent melting at 10kbar of a biotite- and amphibole-bearing tonalitic gnesis: Implications for the generation of A-type granites. Geology, 1993, 21: 263-266

42 McDonough W F, Sun S S, Ringwood A E, et al. K, Rb and Cs in the earth and moon and the evolution of the earth's mantle. Geochim Cosmochim Acta, 1991, Ross Taylor Symposium Volume: 139-156

43 Tayloy S R, McLennan S M. The composition and evolution of the continental crust: Rare earth element evidence from sedimentary rocks. Phil Trans R Soc Lond, 1981, A301: 381-399

44 Chen N S, Wang X Y, Zhang H F, et al. Geochemistry and Nd-Sr-Pb Isotopic Compositions of Granitoids from Qaidam and Oulongbuluke Micro2Blocks, NW China: Constraints on Basement Nature and Tectonic Affinity (in Chinese). Earth Sci-J Chin Univ Geosci, 2007, 32: 7-21

45 Zhang S B, Zheng Y F. Formation and evolution of Precambrian continental lithosphere in South China. Gondwana Res, 2012, doi: 10.1016/j.gr.2012.09.005

Open Access This article is distributed under the terms of the Creative Commons Attribution License which permits any use, distribution, and reproduction in any medium, provided the original author(s) and source are credited. 